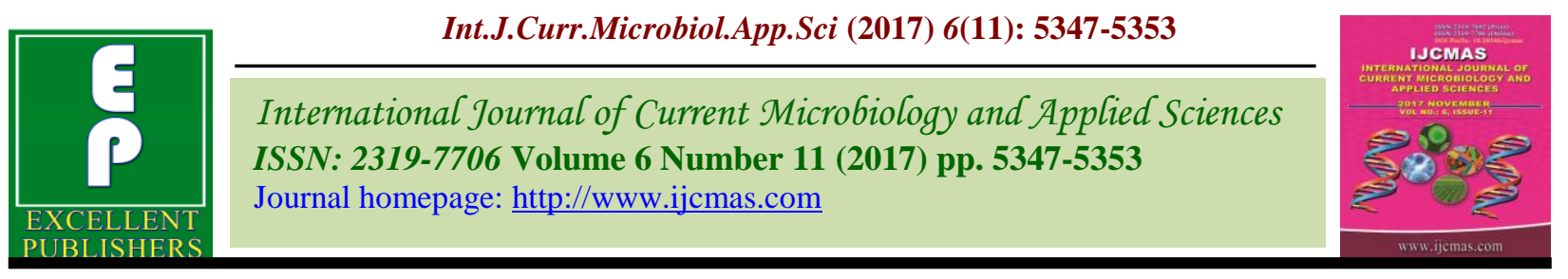

Review Article

https://doi.org/10.20546/ijcmas.2017.611.510

\title{
Micronutrients for Crop Production: Role of Boron
}

\section{Intikhab Aalum Jehangir ${ }^{1 *}$, Shabir H. Wani ${ }^{1}$, M. Anwar Bhat ${ }^{2}$, Ashaq Hussain ${ }^{3}$, Waseem Raja ${ }^{3}$ and A. Haribhushan ${ }^{4}$}

${ }^{1}$ Mountain Research Centre for Field Crops, Khudwani Anantnag-192101, Sher-e-Kashmir University of Agricultural Sciences and Technology of Kashmir, J\&K, India

${ }^{2}$ DARS, Budgam, Sher-e-Kashmir University of Agricultural Sciences and Technology of

Kashmir, J\&K, India

${ }^{3}$ Division of Agronomy, FoA, Wadura, Sher-e-Kashmir University of Agricultural Sciences and

Technology of Kashmir, J\&K, India

${ }^{4}$ KrishiVigyan Kendra, Senapati, Manipur, India

*Corresponding author

\section{A B S T R A C T}

Keywords

Micronutrients,

Crop production, Boron.

Article Info

Accepted:

30 October 2017

Available Online:

10 November 2017
Boron is a micronutrient essential for plant growth and sexual reproduction. Plant requirements for boron are critical but only small amounts are needed to provide adequate growth, hence it is categorised as micro nutrient. Of the mineral nutrients essential for plant growth, boron is frequently considered to have minor role but that does not diminish the importance of boron. Considerable research has been directed for highlighting the importance of boron in crop production. In this regard an effort has been made to spotlight the research for improved role of boron on plants.

\section{Introduction}

In crop production boron (B) is one of the essential micronutrient required for normal growth of most of the crops. However, it was the work of Warington (1923) in England that provided firm knowledge of boron requirement for variety of crops. Among the elements required by plants that are taken up from the soil, B is the only element that is taken up by plants not as an ion, but as an uncharged molecule (Miwa and Fujiwara, 2010). Boron fertilization improves photosynthetic activity, enhances activity of enzymes and plays significant role in protein and nucleic acid metabolism (Kolesnik, 1962). Boron seems to protect plasma membrane against peroxidase damage and helps in maintenance of structural integrity (Ismail and Volker, 1997). Boron is also involved in stomatal regulation (Sharma and Tanuja, 1991). Boron being an enzyme activator and involved in the production of starch required for production of cellulose. It increases the permeability of membrane and thereby facilitating carbohydrate metabolism and transport of carbohydrates through cell membrane. It is involved in lignin synthesis 
and associated with calcium uptake and its utilisation. Boron is also involved in cell formation and development, nitrogen fixation (Lewis, 1980; Parr and Loughmann, 1983). Nitrogen metabolism, active salt absorption, hormone, fat, phosphorus metabolism and photosynthesis.

Sexual reproduction in plant is more sensitive to low $\mathrm{B}$, than vegetative growth. Boron needed for growth of the pollen tube during flower pollination and therefore important for good seed set and fruit development. Boron is thought to increase nectar production by flowers, and this attracts pollinating insects. B in crop production is one of the essential micronutrient required for normal growth of most of the crops.

\section{Role of boron in different crops}

Boron application has proved beneficial in increasing the yield of cereals like rice and wheat, oilseeds (rapeseed and mustard) owing to the beneficial effect of boron on reproductive growth of crops like importance of boron in promoting growth of pollen tube and there by establishing positive correlation between boron and number of flowers not aborted and fruit growth (ONiell et al., 2004). However crops also differ among themselves in terms of responsiveness and tolerance of boron (Table 1) as the range of boron is narrow between toxic, sufficiency and deficient. Boron being vital for cell division, cell wall solidification, hormonal growth seed formation and sugar translocation plays an important role in terms of quantity of flowers and weight of seeds (Bolanos et al., 2004). An adequate supply of boron is pre requisite for maintaining the assimilate supply to the developing grains (Dixit et al., 2002). Rani. P.S. and Latha (2017) found that addition of boron alone resulted an increase of $1.37 \mathrm{t} \mathrm{ha}^{-1}$ over control owing to $45 \%$ increase in filled grains, highest among treatments. An improvement in number of tillers plant ${ }^{-1}$, panicle length, straw and paddy yield of rice was observed by Mehmood et al., (2009) due to application of boron @ $1.5 \mathrm{~kg} \mathrm{~B} \mathrm{ha}^{-1}$ to salt affected soils (Saline and saline-sodic). The other possible reason for improved yield could be due to ion exclusion process in plants. Application of $1.5 \mathrm{~kg} \mathrm{~B} \mathrm{ha}{ }^{-1}$ in soil culture and 200-400 $\mathrm{ng} \mathrm{B} \mathrm{mL} \mathrm{mL}^{-1}$ in solution culture accompanied with low concentration of saline ions $\left(\mathrm{Na}^{+}, \mathrm{Cl}^{-}\right)$by the dilution effect resulted in improved growth and yield in different rice cultivars. Due to its immobile nature Born is sprayed to foliage particularly at the time of flowering for yielding improved results as rapid synthesis of cell wall and plasma membrane are important for growth of pollen tubes (Tiaz and Zeiger, 2010). Rehman et al., 2014 observed increase in kernel yield of foliage applied boron owing to substantial decrease in panicle sterility and increase in grain size.

Boron application in wheat has been observed to increase the yield because of the significant role of boron in reproductive growth (Anther, pollen and ovule development). Boron application is warranted in crops like wheat for improved yield, owing to limited phloem mobility (Cakmak, 1994). Grain un-filling in wheat can be overcome by boron application as normal ear fails to flower and development of inflorescence and setting of spikelets is restricted due to boron deficiency (Rerkasem and Jamjod, 2004). Fakir et al., (2016) registered significantly higher number of spikelets spike ${ }^{-1}$, number of grains spike $^{-1}$, 1000 seed weight and grain yield after boron application.

Boron is an essential nutrient for rape (Brassica napus L.) which influences the oil content in seeds. Varenyiova and Ducsay (2014) registered increase in oil content compared to treatment fertilized with nitrogen and sulphur alone indicating the possible role 
of boron for increased oil yield of (Brassica napus L.). The application of born in sunflower has also shown improvement in yield.

Al-Amery et al..,(2011) observed increase in yield of sunflower crop in response to boron application with 200 and $250 \mathrm{mg} \mathrm{L}^{-1}$ proving significant which was attributed to decrease in seed sterility percentage $(5 \%)$ and small but incremental increase in seed size. Similar results were observed by Saleem et al., (2016) who registered maximum number of achenes per head (397) with the yield of (32.2 g plant $^{-1}$ ) from the pots receiving boron @ $4 \mathrm{~kg}$ $\mathrm{ha}^{-1}$ and the lower number of achenes (319) with the yield of (14.9 $\left.\mathrm{g}_{\text {plant }}{ }^{-1}\right)$ were recorded from the control plots (without boron application).

\section{Deficiency of boron}

Singh (2001) explored that out of 36,825 soil samples collected throughout India, 33\% were deficient in B. In India, laterite and lateritic soils (Ferralsols and DystricNitisols) have been widely reported for the deficiency of $\mathrm{B}$. Boron deficiencies are also more pronounced during drought periods when root activity is restricted.

Boron deficiencies are generally related to high rainfall and acidic soil conditions owing to its increased water solubility in acid soil conditions leading to leaching of boron. While as under alkaline soils the deficiency is associated with less solubility and less uptake. Boron deficiency is one of the major constraints to crop production (Sillanpaa, 1982), and has been reported in more than 80 countries and for 132 crops over the last 60 years (Shorrocks, 1997) Boron deficiency has been commonly reported in soils which are highly leached and/or developed from calcareous, alluvial and loessial deposits (Borkakati and Takkar, 2000). Several soil factors and conditions render soils deficient in B. For example, low soil organic matter content, coarse/sandy texture, high $\mathrm{pH}$, liming, drought, intensive cultivation and more nutrient uptake than application, and the use of fertilizers poor in micronutrients are considered to be the major factors associated with the occurrence of B deficiency (Rashid et al., 2005; Niaz et al., 2007)

Deficiency of boron causes different effects on very diverse processes in vascular plants such as root elongation, IAA oxidase activity, sugar translocation, carbohydrate metabolism, nucleic acid synthesis and pollen tube growth, Goldbach and Wimmer (2007). Boron deficient plants continue to undergo cell division without cell differentiation which otherwise result in cells becoming organs such as leaves, stem etc. when soil are low in boron crops tend to show deficiency symptoms, requirement also depends on the type of crop viz, legumes have high boron requirement, while grasses and cereals have low requirement. In the absence of boron pollen tubes may rupture due to primary role of boron in cell wall structure of pollen tube (Brown et al., 2002).

A recent study showed that at least three potentially B-binding membrane glycoproteins were neither detected in Bdeficient pea nodules nor in other B-deficient plant tissues, which could indicate that $\mathrm{B}$ and certain membrane glycoproteins are involved in membrane processes associated with general cell growth (Redondo-Nieto et al., 2007). Deficiency symptoms of boron in cereals are rare, despite low soil boron levels e.g. wheat forms normal head but does not flower, dead growing points distorted blossom development and finally Seed formation is affected. In barley heads are not formed. In rice emerging leaves become white and rolled delayed maturity and causes sterility. While oats do not develop full pollen 
tube resulting in improper pollination and consequently reduction in yield. Growth is restricted, epical bud dries up, pod formation is affected ultimately decreases the seed size in Rapeseed and Mustard. In Ground Nut Chlorosis and browning of leaves occurs and seeds exhibit black colour and reduced size (Mookherjee and Mitra, 2016).

\section{Factors affecting boron availability}

Boron nutrition is influenced by many factors the most important ones are soil texture, organic matter content, and $\mathrm{pH}$.

\section{Soil texture}

Boron is readily leached out of soil by excessive rainfall or irrigation especially in coarse textured soils i.e. more coarse the texture of soil more will be leaching of boron and thus less availability. Coarse-textured soils often contain less available B than finetextured soils (Malhi et al., 2003).

\section{Soil organic matter content}

Organic matter being one of the primary sources of boron releases boron after microbial action. Crops grown in soils low in organic matter content require more frequent boron fertilization. Organic matter (OM) is the storehouse for most nutrients in soil and is known to improve soil health and availability of plant nutrients. Many researchers have suggested that the level of soil organic matter (SOM) influences the nutrient bioavailability (Sarwar and Mubeen, 2009).

Table.1 Relative crop responsiveness and tolerance to boron fertilizer

\begin{tabular}{|c|c|c|}
\hline High & Medium & Low \\
\hline Alfalfa & Asparagus & Barley \\
\hline Apple & Carrot & Beans \\
\hline Beets & Cherry & Cucumber \\
\hline Broccoli & Corn & Grasses \\
\hline Brussels & Lettuce & Oat \\
\hline Sprouts & Onion & Peas \\
\hline Cabbage & Peach & Rye \\
\hline Cauliflower & Pear & Sorghum \\
\hline Celery & Potato & Wheat \\
\hline Mustard & Radish & \\
\hline Sunflower & Spinach & \\
\hline Turnip & Potato & \\
\hline & Soybean & \\
\hline & Tomato \\
\hline
\end{tabular}

Table.2 Boron fertilizers

\begin{tabular}{|l|l|l|}
\hline Material & Chemical formula & Boron (\%) \\
\hline Borax & $\mathrm{NaB}_{4} \mathrm{O}_{7} \cdot 10 \mathrm{H}_{2} \mathrm{O}$ & 11.3 \\
\hline Boric acid & $\mathrm{H}_{3} \mathrm{BO}_{3}$ & 17.5 \\
\hline Fertilizer borate & $\mathrm{Na}_{2} \mathrm{~B}_{4} \mathrm{O}_{7} \cdot 5 \mathrm{H}_{2} \mathrm{O}$ & 15.0 \\
\hline Anhydrous Borax & $\mathrm{Na}_{2} \mathrm{~B}_{4} \mathrm{O} 7$ & 21.1 \\
\hline Solubor & $\mathrm{Na}_{2} \mathrm{~B}_{8} \mathrm{O}_{13} \cdot 4 \mathrm{H}_{2} \mathrm{O}$ & 4.9 \\
\hline
\end{tabular}


The strongest evidence that $\mathrm{OM}$ affects the availability of soil B is derived from studies that show a positive correlation between levels of SOM and the amount of hot-watersoluble B (Shafiq et al., 2008).

\section{Soil pH}

Boron deficiencies are more prevalent in soils with $\mathrm{pH}$ levels near or above 7.0. Liming acid soils with marginal levels can also cause crop and pasture plants to become deficient. The larger the quantity of lime applied, greater is the possibility of crops exhibiting deficiency symptoms. Thus the plants should be closely monitored after lime is applied to crop. There is a close association with the $\mathrm{pH}$ of the soil solution and the level of soluble B in soils (Niaz et al., 2007). In several studies, highest levels of B adsorption by soil depicted close correlation with the $\mathrm{pH}$ of the soil solution (Shafiq et al., 2008).

\section{Drought}

Boron deficiencies are more prevalent in crops growing under drought stress especially when dry period follows a wet winter after much of the available boron has been leached from the root zone. Dry conditions are thought to induce boron deficiency by restricting the root activity in dry surface soils and decreased microbial activity. Boron bioavailability decreases under drought condition because of reduced mobility of $B$ from soil by mass flow to roots (Barber, 1995.Thus more the drought more the crop plants tend to exhibit boron deficiency symptoms which can be overcome by frequent irrigations, provided the soil is adequate in boron.

\section{Boron management}

Boron can be applied to both perennial and annual crops either in spring or during fall in the form of different fertilizers (Table 2) through soil application, foliar application and seed treatment depending upon the convenience and requirement. However, the application of boron is limited to only spring application on coarse textured soils. Boron should be applied as broadcast followed by incorporation, as continuous supply of boron is required by plants from germination to maturity depending on soil and crop test level. Surface broadcast application on hay crops is an effective application technique.

The immobile nature of boron in plants necessitates the foliar application in crops, though field crops are rarely treated with foliar application of boron, however higher boron rates can be supplied through foliar application if followed by substantial rainfall or irrigation, ensuring that only small portion is absorbed through foliage with the remainder washing off, entering the soil and then its uptake by plant roots. Boron can also be applied in combination with some pesticides as foliar application provided there is proper compatibility to that particular pesticide and also reducing application cost. Once the deficiency of boron is experienced in the form of symptoms exhibited by the crop or by soil testing, boron can be applied as soil application, in the form of foliar application and seed treatment depending upon the ease of the operation. For soil application boron is applied in the form of borax@10-15 kg ha-1 , boron deficiency can also be overcome by its foliar application as borax@0.25-0.50\% with 1 or 2 sprayings before flowering depending on severity. Borax can also be applied to seed as seed treatment by soaking the seed in $1 \%$ borax solution for 2 hrs.

\section{Residual effects}

Residual effect of boron in soils depends on various factors like rate of application, soil type, amount of irrigation, or rainfall. So care is needed as excessive use of boron can be 
damaging. Recommended rates of boron fertilizer have life expectancy of three years on all soils except sandy and free draining soils, or those with very low clay and organic matter content. Foliar sprays have no long term effect, and usually need to be repeated for each crop, sometimes several times during the season.

\section{Boron toxicity}

Boron an essential micro nutrient has narrow range between deficiency and toxicity than any other element (Goldberg, 1997), thus application of boron needs critical examination to avoid toxicity, exhibited in the form over fertilization or concentrating boron near seedling crops. Soil boron levels greater than $(2 \mathrm{ppm})$ shows the potential for toxicity in boron sensitive crops like cereals and grasses. The boron toxicities can be overcome by careful application, like following the recommended rates, cultivation after band application etc.

Optimum plant growth response can be gained by making sure plants are provided adequate supply of all essential nutrients. Based on the soil test results, boron deficiencies or toxicities can be identified and corrected before or after planting for getting higher and quality produce.

\section{References}

Ahamad, W., Niaz, A., Kanwal, S., Rahmatullah and Rasheed, M. K. (2009). Role of boron in plant growth: A review. J. Agric. Res. 47(3): 329-338.

Al-Amery, M. M., Hamza, J. H., and Fuller, M. P. (2011). Effect of Boron Foliar Application on Reproductive Growth of Sunflower (Helianthus annuus L.) International Journal of Agronomy. 2011: 1-5.

Barber, S. A. (1995). Soil nutrient bioavailability: a mechanistic approach. John Wiley and Sons, New York, NY, U.S.A.

Bolanos., L. Lukaszewski., K. Bonilla, I. and Blevins, D. (2004). Why boron? Plant
Physiology and Biochemistry 42: 907-912.

Borkakati, K. and Takkar, P. N. (2000). Forms of boron in acid alluvial and lateritic soils in relation to ecosystem and rainfall distribution. In: Proceedings of International Conference on Managing Resources for Sustainable Agricultural Production in the $21^{\text {st }}$ Century. BetterCrops. Vol. 2, pp. 127-128.

Brown, P.H., Bellaloui, N., Wimmer, M.A., Bassil, E.S., Ruiz, J. Hu. H., Pfeffer, H., Dannel, F. and Römheld,V. (2002) Boron in plant biology. Plant Biology 4: 205-223.

Cakmak, I. (1994). Activity of ascorbatedependent $\mathrm{H}_{2} \mathrm{O}_{2}$-scavenging enzymes and leaf chlorosis are enhanced in magnesiumand potassium-deficient leaves, but not in phosphorus-deficient leaves. J. Exp. Bot. 45:1259-1266.

Dixit, D., Srivastava, N.K., Sharma, S. 2002. Boron deficiency induced changes in translocation of $14 \mathrm{CO}_{2}$-photosynthate into primary metabolites in relation to essential oil and curcumin accumulation in turmeric (Curcuma longa L.). Photosynthetica.40, 109-113.

Fakir., O. A.,Rahman., M. A. and Jahiruddin., M. (2016).,2016.Effect of foliar application of boron(B) on the grain set and yield of wheat (Triticumaestivum L.). American Journal of experimental Agriculture. 12(2): 1-8.

Goldbach, H.E. and Wimmer., M. (2007). Boron in plants and animals: Is there a role beyond cell-wall structure? J. Plant Nutr. Soil Sci. 170:39-48.

Goldberg, S. (1997). Plant and Soil. 193: 35 - 48.

Ismail, C. and Volkar, R. 1997. Plant and soil 1993:71-83.

Kolesnik, L. V. (1962). Proc. Kishinev. Agr. Inst., 27: 3-9.

Lewis, D.H. (1980). New phytol 84:209-229.

Malhi, S. S., Raza, M., Schoenau, J. J., Mermut, A. R., Kutcher, R., Johnston, A. M. and Gill, K. S. (2003). Feasibility of B fertilization for yield, seed quality, and B uptake of canola in north eastern Saskatchewan. Canadian Journal of Soil Science.Vol. 83, pp. 99-108.

Mehmood, E. H., Kausar, R., Akram, M. and Shahzad. S.M. (2009). Is boron required to 
improve rice growth and yield in saline environment. Pak. J. Bot. 41(3)1339-1350.

Miwa, K. and Fujiwara, T. (2010). Boron transport in plants: co-ordinated regulation of transporters. Annals of Botany. Vol. 105, pp. 1103-1108.

Mookherjee, S. and Mitra. B (2016). Role of Sulphur, Boron and Zinc Nutrition in Field Crops and Their Status in Eastern SubHimalayan Plains of India. Imperial Journal of Interdisciplinary Research. 2 (9) 11801184.

Niaz, A., Ranjha, A. M., Rahmatullah, Hannan, A. and Waqas, M. (2007). Boron status of soils as affected by different soil characteristics$\mathrm{pH}, \mathrm{CaCO}$, organic matter and clay contents. Pakistan Journal of Agricultural Sciences. Vol. 44, pp. 428-435.

O'Neill, M.A., Ishii, T., Albersheim, P. and Darvill, A.G. (2004). Rhamnogalacturonan II: structure and function of a borate cross linked cell wall pectic polysaccharide. Annual Review of Plant Biology 55: 109139.

Parr, A. J. and Loughmann, B. C. (1983). In: Metals and Micronutrients Uptake and Utilization by Plants. Academic Press, New York, pp.87-107.

Rani, P.S. and Latha, A. (2017).Effect of calcium, magnesium and boron on nutrient uptake and yield of rice in Kole lands of Kerala. Indian J. Agric. Res. 51 (4): 388-391.

Rashid, A., Muhammad, S. and Rafique, E. (2005). Rice and wheat genotypic variation in boron use efficiency. Soil Environ Vol. 24, pp. 98-102.

Redondo-Nieto M, Pulido L, Reguera M, Bonilla I, Bolanos L (2007). Developmentally regulated membrane glycoproteins sharing anti- genicity with rhamnogalacturonan II are not detected in nodulated boron deficient Pisum sativum. Plant Cell Environ. 30, 1436-1443.
Rehman, A., farooq, M., Cidheema, Z. A.,Nwaz, A. and Wahid, A. (2014).Foliage applied boron improves the panicle fertility, yield and biofortification of fine grain aromatic rice. Journal of Soil Science and Plant Nutrition.14 (3), 723-733.

Rerkasem., B. and Jamjod., S. (2004). Boron deficiency in wheat: A review. Field Crops Research. 89: 173-186.

Sarwar, N. and Mubeen, K. (2009). Nutrient deficiency in rice crop.DAWN [Online] Available: 24August. http://www.dawn. $\mathrm{com} / \mathrm{wps} / \mathrm{wcm} / \mathrm{connect/dawn-content-}$ library/dawn/in-paper-magazine/economicand-business/nutrient-deficiency-in-ricecrop-489 [15 May 2010]

Shafiq, M., Ranjha, A. M., Yaseen, M., Mehdi, S. M. \&Hannan, A. (2008). Comparison of freundlich and Langmuir adsorption equations for boron adsorption on calcareous soils. Journal of Agricultural Research. Vol. 46, pp. 141-148.

Sharma, P. N. and Tanuja, R. (1991). Indian J. Exptl. Biol. 29(10): 967-970.

Shorrocks, V. M. (1997). The occurrence and correction of boron deficiency. Plant and Soil. Vol. 193, pp. 121-148.

Sillanpaa, M. (1982). Micronutrients and nutrient status of soils, a global study. In: FAO Soil Bulletin. No. 48, Rome, Italy.

Singh, M. V. (2001). Evaluation of micronutrient stocks in different agroecological zones of India. Fertilizer News. Vol. 42, pp. 25-42.

Taiz, L. and Zeiger, E. (2010). Plant Physiology, 5th Edition. Sinauer Associates, Inc., Sunderland, MA.

Varenyiova, M. and Ducsay, L. (2014).Effect of increasing doses of boron on oil production of oilseed rape (Brassica napusL.). Mendel net. 110-114.

\section{How to cite this article:}

Intikhab Aalum Jehangir, Shabir H. Wani, M. Anwar Bhat, Ashaq Hussain, Waseem Raja and Haribhushan, A. 2017. Micronutrients for Crop Production: Role of Boron. Int.J.Curr.Microbiol.App.Sci. 6(11): 5347-5353. doi: https://doi.org/10.20546/ijcmas.2017.611.510 